\title{
Growth prediction of sago palm (Metroxylon sagu) in Thailand using the Linear Mixed-effect model
}

\author{
MALIMAS JARIYAPONG ${ }^{1, »}$, SAOWALAK ROONGTAWANREONGSRI ${ }^{1}$, ARISARA ROMYEN ${ }^{2}$, \\ BUNCHA SOMBOONSUKE ${ }^{3}$ \\ ${ }^{1}$ Environmental Economics Research Unit, Faculty of Environmental Management, Prince of Songkla University. 15 Karnjanavanich Rd., \\ Hat Yai, Songkhla, 90112, Thailand. Tel.fax.: +668-4198-8808, `email: pmjsan2526@ gmail.com \\ ${ }^{2}$ Department of Agribusiness Economics and Management, Faculty of Economics, Prince of Songkla University. 15 Karnjanavanich Rd., \\ Hat Yai, Songkhla 90112, Thailand \\ ${ }^{3}$ Department of Agricultural Development, Faculty of Natural Resources, Prince of Songkla University. 15 Karnjanavanich Rd., \\ Hat Yai, Songkhla 90112, Thailand
}

Manuscript received: 22 July 2021. Revision accepted: 10 October 2021.

\begin{abstract}
Jariyapong M, Roongtawanreongsri S, Romyen A. Somboonsuke B, 2021. Growth prediction of sago palm (Metroxilon sagu) in Thailand using the Linear Mixed-effect model. Biodiversitas 22: 5293-5301. A living sago palm is a potential resource for carbon sequestration in peat swamp. It can provide benefits for agriculturists and environmental sustainability. This study's aim is to create a growth prediction of sago palm size at individual ages using a linear mixed-effect model. The sample palms were selected from 43 sago palm parents which have been re-measured and recorded at intervals of 2-20 years. The experimental plot was on deep peat soil (with peat depth at over $2.5 \mathrm{~m}$ ) at Phru Todaeng Swamp Forest, Southern Thailand. To find the best model for growth prediction, we used a traditional linear model (Model 1 and 4) and linear mixed-effect models (Model 2, 3, 5 and 6) to generate the relationship between age, diameter, and height. The best model was selected based on considering the smallest Akaike's Information Criteria (AIC), the Bayes Information Criteria (BIC), and the absolute mean error (AME). The results showed the smallest values of AIC, BIC, and AME in Model 3 which produced the best model for predicting the total overall growth in sago palm. The age and diameter under the independent variable were statistically significant $(\alpha=0.01)$; these two factors influenced the sago palm height rate. Hence, this model can be used to predict the overall growth of sago palms, which is useful for biomass estimation and calculating the carbon sequestration of planted sago palms. The carbon sequestration in living sago palm can be compared with other commercial crops for future benefit. This approach can lead to a future solution for wetland management and land-use changes.
\end{abstract}

Keywords: Biomass estimation, carbon sequestration, converted wetland, deep peat soil, palm growth parameter

\section{INTRODUCTION}

In recent decades, peat swamp forest area in Southeast Asia has been largely converted into monoculture crops, particularly paddy fields, sugar cane, and oil palm plantations (Green and Page 2017). For instance, peat swamp forest areas in Indonesia and Malaysia decreased from $77 \%$ to $29 \%$ between 1990 to 2015 while the industrial plantation expanded to $34 \%$ of the deforested area (Miettinen et al. 2012, 2016). This conversion of peat swamp forests was a major cause of wetland degradation and ecosystem services loss, particularly in lost carbon stock, resulting in a high rate of carbon dioxide $\left(\mathrm{CO}_{2}\right)$ emission. $\mathrm{CO}_{2}$ emissions from Southeast Asian converted peatland areas were reported to release 2.42 million $\mathrm{M}_{\mathrm{g}} \mathrm{CO}_{2 \mathrm{e}} \mathrm{yr}^{-1}$ (Koh et al. 2011). This impact is directly related to climate change as $\mathrm{CO}_{2}$ emission has the potential to influence temperature changes in the global climate and subsequent changes in climate patterns (IPCC 2021).

To counteract this problem, Indonesian and Malaysian governments have promoted cultivation of sago palm (Metroxylon sagu Rottb.; Arecaceae) as a commercial crop in peat swamps, as one approach to solve the problem of land use and land cover change (Bintoro et al. 2018; Uda et al. 2020). Sago palm is particularly chosen because of many reasons. First, it grows well in the wetlands of Southeast Asia. Second and more importantly, sago palm provides a variety of ecosystem services, including provisioning services and regulating services. For provisioning services, sago starch and fronds have been used as raw materials (Toyoda 2015), fiber as animal feed, and sago weevil as food (Chanta 2017). Sago starch, in particular, has been utilized as a raw material for various kinds of industries such as food, paper, adhesives, textiles, plywood, and cosmeceuticals, all of which generate income for the country of cultivation (Hirao et al. 2018; Ohmi 2015). For regulating services, the sago palm is known for its capacity to store $\mathrm{CO}_{2}$ (Food Agriculture and Organization 2014), and conserve water in the soil (Bintoro et al. 2018). In doing so, the sago palm has advantages over other commercial crops due to its greater ability to contain $\mathrm{CO}_{2}$ (Hergoualc'h and Verchot 2014) and moisture in the soil (Thorburn and Kull 2015). In addition, it requires no chemicals to eliminate weeds and pests (Naim et al. 2016)

Wulan et al. (2015) studied the $\mathrm{CO}_{2}$ emission of sago palm, oil palm, and paddy planted in Indonesia peatland. They used the life cycle assessment concept to evaluate the potential environmental impact of activities, starting from 
the plantation, maintenance and harvesting, transportation, and factory production process, until returning the waste to nature. The results showed that sago palm emitted the lowest $\mathrm{CO}_{2}, 214.75 \mathrm{~kg} \mathrm{CO}$ eq, while oil palm and paddy emitted $406.88 \mathrm{~kg} \mathrm{CO} \mathrm{CO}_{2} \mathrm{eq}$ and $322.03 \mathrm{~kg} \mathrm{CO} \mathrm{CO}_{2}$ eq, respectively. Although the sago palm still releases $\mathrm{CO}_{2}$, this emission is less than other commercial crops for the region. Hence, promoting sago palm cultivation as a commercial crop is a plausible potential alternative as it can provide benefits for the ecosystem, environment, and economy.

One of sago's ecosystem services of great interest is carbon storage. Carbon stored in a living tree is an important means of carbon storage in an ecosystem (Fahey et al. 2010). A living tree, which grows each year, absorbs $\mathrm{CO}_{2}$ from the atmosphere through the process of photosynthesis and stores it in biomass both below and above the ground, in the root, trunk, branches, and leaves. This process shows a tree to be a form of carbon storage with annual biomass increment (Vashum and Jayakumar 2012). Sago palm has an advantage in this respect because once transplanted, sago palms can produce new suckers continuously and each clump needs 6-8 palms to be kept at different ages for continuous harvesting every year (Ando 2015). Thus, it represents a large resource of living trees that can store carbon without replanting.

Usually, to calculate the carbon storage potential, various biomass equations are used. In these equations, one of the parameters required is the annual growth of the plant, including indicators such as tree diameter at breast height and total height. These indicators are usually determined using growth rate prediction. However, since the diameter of palm trees does not change much (Goodman et al. 2013), most palm biomass equations (such as in Goodman et al. 2013; Morel et al. 2011; Pearson et al. 2013; Rodríguez 2017) were developed from a height parameter only (Pearson et al. 2013). It was also generally considered that there is no relationship between the palm's height and diameter (Rodríguez 2017). Previous studies on growth rate prediction are common for other commercial palm crops, for instance, Welfia georgii H.Wendl. (Lieberman et al. 1988) and oil palm (Elaeis guineensis Jacq.) (Hoffmann et al. 2014). However, as Nabeya et al. (2015) observed, the young sago palm's diameter increases exponentially after transplanting and gradually increases slowly on maturity. Therefore, to make a more accurate prediction, we assume that the sago palm diameter parameter is related to volume increment. Some studies are applying the linear mixed-effect model to generate the tree growth model to solve inaccurate predictions in the regression model, such as indigenous neotropical species (Centrolobium tomentosum) (de-Miguel et al. 2013) and Scot pine (Pinus sylvestris L.) (Socha et al. 2021). However, to the authors' knowledge, previously, no study has directly predicted the growth rate for sago palm. For example, previous literature on the sago palm has focused on the relationship between growth size and the potential for starch accumulation in trunk pith; that is, Yamamoto et al. (2003, 2010) and Yanagidate et al. (2009) compared sago palm's growth rate and starch content in different soil types, but not carbon storage in a living sago palm. Although long-term carbon storage can provide indirect benefits for human beings and lead to environmental sustainability, the estimated rate of carbon storage in sago palms is still a gap in the literature.

This study's objective is therefore to create a suitable model for predicting sago palm growth at individual ages using a non-destructive sampling to aid the estimation of biomass increment and carbon sequestration. The result is expected to fulfill the identified gap concerning carbon storage estimation in sago palm for its whole life cycle. This information can also be compared with that for other commercial crops, particularly oil palm, and can be used for wetland management in the future.

\section{MATERIALS AND METHODS}

\section{The study area}

This research used a secondary data set about Phru Todaeng Swamp Forest (6 $\left.{ }^{\circ} 04^{\prime} 15.3^{\prime \prime} \mathrm{N}, 101^{\circ} 58^{\prime} 05.8^{\prime \prime} \mathrm{E}\right)$ from Pikulthong Peat Swamp Forest Research Station, Pikun Thong Royal Development Study Center, in Narathiwat Province, Southern Thailand. An experimental plot was established on the development zone which was converted from primary forest to degraded forest by drainage and forest fire. The peat soil had a high level of organic matter $(>30 \%)$ with a depth of more than $2.5 \mathrm{~m}$, and a soil $\mathrm{pH}$ of $\sim 4.31$. The climate is fundamentally a tropical rain forest type, and annual rainfall averages 1500$2000 \mathrm{~mm}$ (Hydroinformatics Institute 2020), falling almost throughout the entire year with no distinct long dry season.

\section{Sample plot and data selection}

All sago palms in this study are a non-spiny type which was transplanted to the experimental plot from 1997 to 2016. The experimental plot had six blocks with $8 \times 8 \mathrm{~m}$ and $10 \times 10 \mathrm{~m}$ spacings between planting. Each block was transplanted with 36 suckers. No fertilizer application, sucker pruning, pest control, and weed management was performed on the plot. This study selected only parent sago trees to be included in the sample. We did not use data on suckers from such parent trees. The parent trees were planted using a sucker, tagged, and observed their survival. If they survived the first year, then DBH was measured annually. Those trees that did not survive the next 20 years were not included in the model. The suckers from each parent tree were also measured for DBH; however, we did not use the data of suckers in the models. Over 20 years, measurements for 76 surviving parent sago palms were recorded; however, to ensure analysis accuracy, we selected only 43 parent trees that had a complete growth record dataset from the age of two to 20 years old as a sample size for growth prediction.

Metroxylon sagu is soboliferous. Generally, sago palm can be propagated by transplanting suckers. After 1-3 years of transplanting, the suckers emerge from the parent stem and form trunks away from their parent trunk. The life cycle of the sago palm has four major stages. In the first stage, the Rosette stage (4-5 years), the diameter growth of 
the main creeping sucker is increased rapidly (Nabeya et al. 2015). During the second stage, the Bole formation, the stem elongates and begins to form the trunk until growing into the inflorescence (the third stage) and fruit-ripening stage (the fourth stage). In the second stage, the diameter gradually increases slowly and takes about 6-17 years. In the third stage, flower buds start to form, which takes about two years to flowering and another year to fruiting. When the fruits have fully ripened, the life cycle is completed. The sago palm withers and dies after the flowering-fruiting stage (Nitta 2015).

To accurately measure sago palm growth sizes in terms of diameter and total height, the sampled palms were separated into two groups: young (2-5 years) and mature sago (6-20 years) because growth patterns differ between young and mature sago palms. In the young (period before the trunk is formed) and the mature sago palms (having clear trunk formation), the diameter was measured at $20 \mathrm{~cm}$ and $1.30 \mathrm{~m}$ above ground level, respectively. The total height was measured from the ground to the highest point of the highest frond. The diameter and total height of each sampled palm were individually measured by a diameter tape and a measuring pole, respectively. Table 1 shows the diameters and total heights of sampled sago palms at different stages.

\section{Growth model development}

Generally, the traditional linear regression method is widely used to generate a model prediction for tree growth, for example, Dipterocarpus costatus C.F. Gaertn., Haldina cordifolia, (Roxb.) Ridsdale, and Dipterocarpus alatus Roxb. ex G.Don (Saaludin et al. 2014) Macaranga gigantea (Rchb.f. \& Zoll.) Müll.Arg. (Susanto et al. 2017), Eucalyptus (Singh and Dhakad 2018) and Hevea brasiliensis Mull-Arg. (Nattharom et al. 2020). In the earlier studies of sago palm, simple linear regression was used to predict the growth rate (Yamamoto et al. 2003, 2010; Yanagidate et al. 2009). Because our dataset consists of re-measurements on the same trees for 20 years, a linear mixed-effect model was considered to be more appropriate as it takes the form of correlated observations.

In principle, using a standard cross-sectional regression approach through longitudinal datasets allows higher variation since all relevant observations are of the betweensubjects type. In contrast, the repeated measure approach provides lower variations for within-subject observations, in which individuals are assumed to be observed as a single or a block. The mixed model handles both fixed effects (differences between groups to be the same) and random effects (in particular manners the within-subject observations) that deal with the use of residual covariance structures. This prediction model will be more accurate than using the linear regression method in such a case (Bohora and Cao 2014).
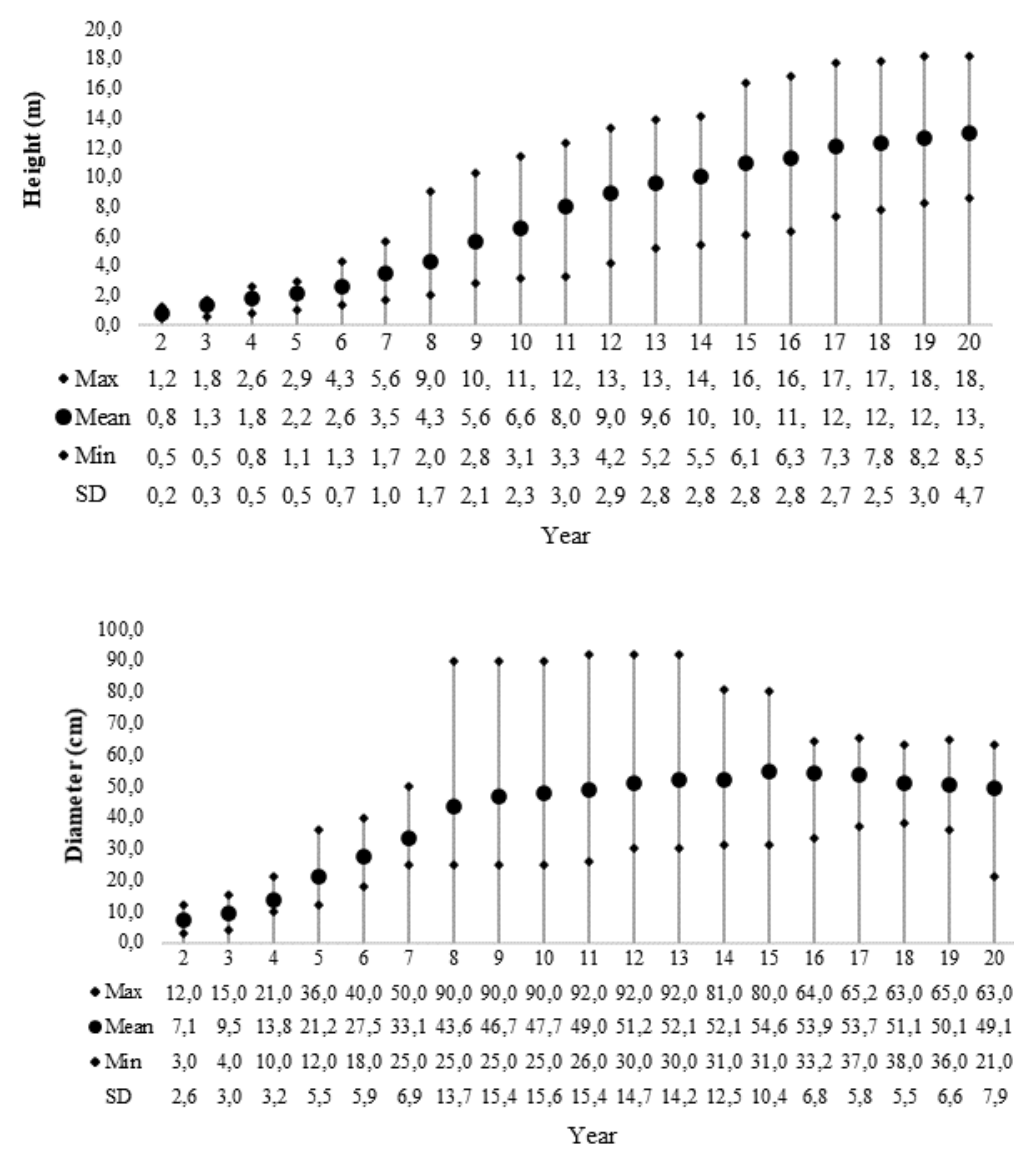

Figure 1. Diameter and height of sampled sago palms at different ages. Number of sago palms at individual age $=43$ 
The linear mix-effected model can combine both fixedeffects parameters common to all trees and random effects specific to each tree. The matrix notation for a mixed method is as follows.

$$
y \quad=X \beta+Z \mu+\varepsilon_{x}
$$

Where: $y$ is the vector of observations, with mean $E(y)=X \beta_{x} \beta$ is an estimated vector of fixed effects, $\mu$ is an unknown vector of random effects, with mean $E(\mu)=0$ and variance-covariance matrix $\operatorname{var}(\mu)=G$,

$\varepsilon$ is an unknown vector of random errors, with mean $E(\varepsilon)=0$ and variance $v a r(\varepsilon)=R, X$ and $\mathrm{Z}$ are involved in designing matrices responding to the observation $y$ to $\beta$ and $\mu$, respectively

As mentioned earlier, palm growth prediction usually requires only the total height parameter to generate the tree volume and biomass equation. However, we noticed the different growth patterns between the young and mature sago palms. Thus, it will be more accurate if the growth of sago palm can be predicted differently for the young and the mature stage. Therefore, this study will forecast the dependent variable (the growth rate of the height) from the independent variables (the age and the diameter) of sago palms.

To take into account the obstacle of correlated withinsubject errors for longitudinal quantitative analysis, we have selected the linear mixed-effect model to forecast the growth rate. To confirm that this model is the most suitable, we generated and compared six different models using the traditional and linear mixed-effect models which were analyzed in RStudio (RStudio Team 2020). The traditional linear model (Model 1 and Model 4) and the mixed model were constructed to consider the relationship between the height of the sago palm tree against the age and the diameter (Model 3 and Model 6), whereas Model 2 and Model 5 considers only the relationship between height and age for comparison. We determined Akaike's Information Criteria (AIC) and Bayes Information Criteria (BIC) to compare the best-fitted model. Furthermore, the absolute mean error (AME) was computed to measure the error between the actual figures and the predicted figures. The smaller the error, the better the forecasting ability of that model, according to the AME criterion. The dataset showed that the standard deviation increased from small to large specimens, which may entail the presence of heteroscedasticity. After considering the different forms of diameter growth, residual plots were calculated to check the pattern in residuals against the prediction value. Because both young and mature models presented the heteroscedasticity; therefore, we used the bootstrap approach by repeating the sampling of diameter variable for the response model, i.e., the young and mature sago palms were repeated 5,000 and 8,000 times, respectively.

For the model specification, we fitted the age and diameter as the fixed term, and the individual sago palm tree $(\mathrm{ID}=43)$ is given as the random term. The linear mixed model can be written as:

$$
\mathrm{Y}_{i}=\mathrm{X}+\mathrm{X}_{1}(\text { Age })_{i}+\mathrm{X}_{2}(\mathrm{D})_{i}+\mathrm{Z}_{i}(\mu)
$$

Where: $Y_{i}$ is the individual height of sago palm for plot $i=1,2, \ldots . \mathrm{n}$; $\mathrm{X}$ is the coefficient of the fixed-parameter to be estimated, $X_{1}, X_{2}$ is the coefficient of age and diameter variable; $(\mathrm{Age})_{i},(\mathrm{D})_{i}$ is a fixed parameter vector common to all plot; $Z_{i}$ is the random parameter to a specific vector in an individual sago palm; $\mu$ is the coefficient of the random parameter.

\section{RESULTS AND DISCUSSION}

\section{Statistical test for heteroscedasticity}

Figure 2 shows residual correlations with independent variables and heteroscedasticity test of young and mature sago palm growth models. These plots show symmetrical distribution and no sign of a clear pattern, thus, assuming that the models are a good fit (Figure 2).

\section{Statistical results of the models}

Tables 1 and 2 summarize the statistical results and performances, which compare the linear model and the mixed-model predictions. All of the mixed models of the young (Model 2 and Model 3) and the mature sago palms (Model 5 and Model 6) produced lower values for AIC, BIC, and AME than the traditional linear model (Model 1 and Model 4). In particular, Model 3 and 6 (Height $\sim$ Age + D), in which the height correlates to the age and diameter, is superior to the other four models due to its smaller AIC at -1497.52 and 25299.8, as well as BIC at -1464.63 and 25334.8. Moreover, both Model 3 and 6 provide the lowest AME (7.9202e-4 and 0.1648889e-11). Hence, Model 3 and 6 are the best-fitted model.

To interpret Model 3 and Model 6, the variance component under the random element is statistically significant $(\alpha=0.01)$, implying that the random term significantly affects the response. In this study, the individual tree responds differently to varying environmental conditions. For the fixed effect, the age and diameter are statistically significant $(\alpha=0.01)$, implying that these two factors can essentially predict the height of sago palm trees. If one unit of the age goes up, then the height of the young sago palm and the mature tree increases by 0.321 and 0.681 units. Similarly, if one unit of the diameter expands, then the height of the sago palm tree increases by 0.030 and 0.050 units.

\section{Model validation}

Apart from the lowest values of AIC, BIC, and AME of Model 3 and Model 6, Figure 3 also shows the AME magnitudes, the error value on a diagonal line of the prediction for the six models. Figures 3(c) and 3(f) show the smallest error plot of the obtained residuals near the mean line. Hence, Model 3 and Model 6 produced the lowest values $\mathrm{AIC}$ and $\mathrm{BIC}$, consistent with the smallest error in AME values, implying Model 3 and Model 6 are the most appropriate models for young and mature sago palm growth prediction. 


\section{Growth prediction model}

After finding that Model 3 and Model 6 were the bestfitted models for young and mature sago palm growth prediction, both the growth models were fitted in the mixed-effect model equation: $\mathrm{Y}=\mathrm{X}+\mathrm{X}_{1}($ Age $)+\mathrm{X}_{2}(\mathrm{D})+$ $\mathrm{Z}(\mu)$, where $\mathrm{Y}$ is the height of the individual tree, $\mathrm{X}$ is the coefficient of the fixed-effect variable, $Z$ is the ID whose value is 1 if the observation was coming from stratum 1 and 0 if not, and $\mu$ is the coefficient of the random effect variable.

The expression of the individual-tree growth prediction models were as follows:

(3.1) Young sago palms

Height $=0.003+0.321($ Age $)+0.030(D)+Z(0.323)$

(3.2) Mature sago palms

Height $=-2.515+0.681($ Age $)+0.050(D)+Z(1.9618)$
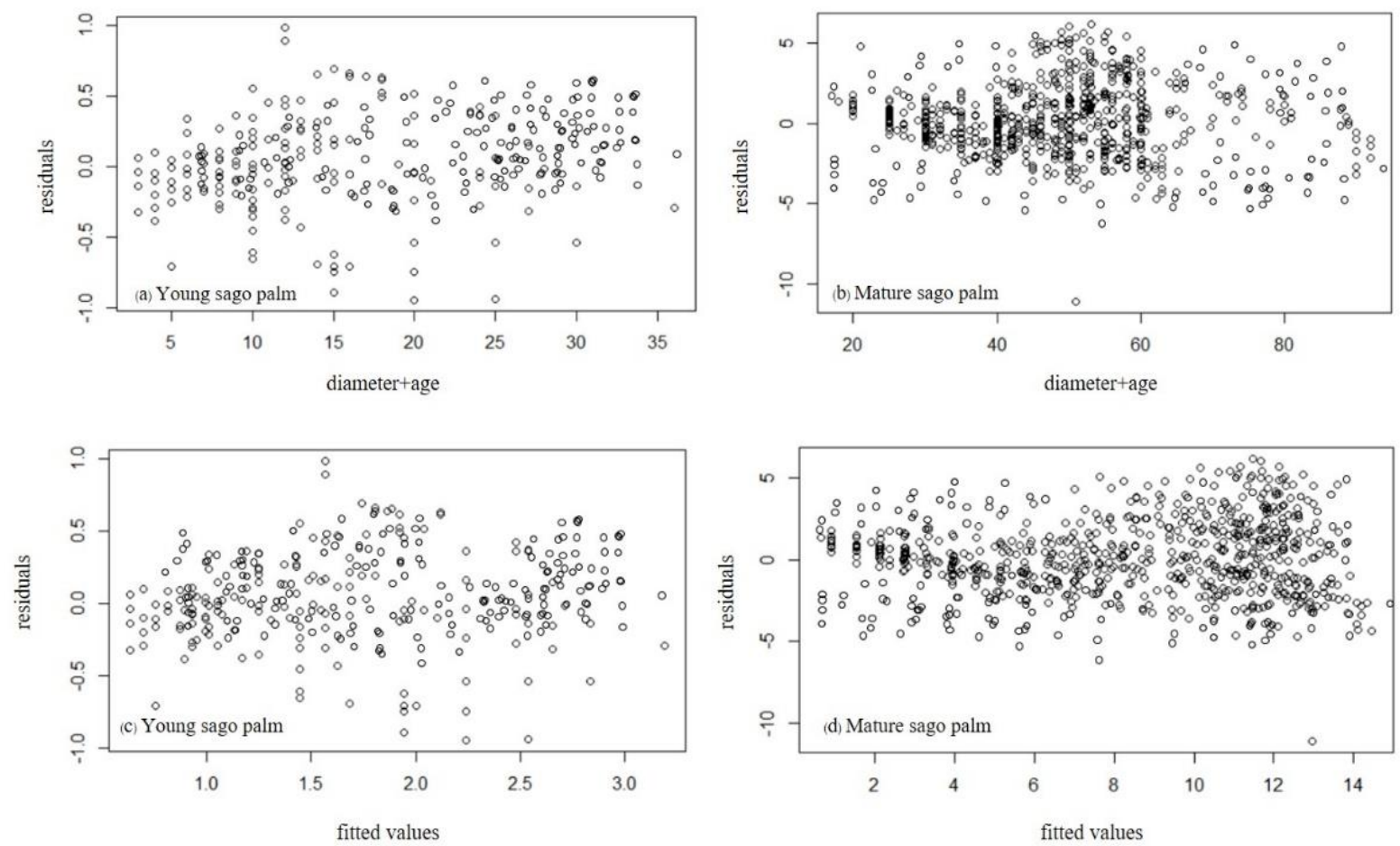

Figure 2. Residual plots of the growth prediction model and graphically of the heteroscedasticity test using the Breush-Pagan test

Table 1. The estimated traditional linear model and the mixed-effect models of the young sago palm (2-5y)

\begin{tabular}{|c|c|c|c|c|c|c|}
\hline \multirow{3}{*}{ Variable } & \multirow{2}{*}{\multicolumn{2}{|c|}{$\begin{array}{l}\text { Linear Model } \\
\text { Height } \sim \text { Age + D } \\
\text { (Model 1) }\end{array}$}} & \multicolumn{3}{|c|}{ Mixed Models } & \\
\hline & & & \multicolumn{2}{|c|}{$\begin{array}{l}\text { 1: Height } ~ \text { Age } \\
\text { (Model 2) }\end{array}$} & & \\
\hline & Coefficient & S.E. & Coefficient & S.E. & Coefficient & S.E. \\
\hline Intercept & $0.632^{* * * *}$ & 0.017 & - & & - & \\
\hline Diameter & $0.059^{* * *}$ & 0.001 & - & & - & \\
\hline Age & $0.197^{* * *}$ & 0.007 & - & & - & \\
\hline \multicolumn{7}{|c|}{ Random Effect: $\sim 1 \mid \mathrm{ID}^{1}$} \\
\hline Var & - & & 0.381 & 0.217 & $0.323^{* * *}$ & 0.204 \\
\hline \multicolumn{7}{|c|}{ Fixed Effects: } \\
\hline Intercept & - & & $-1.104^{* * *}$ & 0.096 & $0.003^{* * *}$ & 0.079 \\
\hline Age & - & & $0.464^{* * *}$ & 0.012 & $0.321^{* * *}$ & 0.004 \\
\hline Diameter & - & & & & $\mathbf{0 . 0 3 0}^{* * * *}$ & 0.004 \\
\hline \multicolumn{7}{|c|}{ Standardized within-group } \\
\hline \multicolumn{7}{|c|}{ Residuals: } \\
\hline $\min$ & -0.939 & & -2.365 & & -2.109 & \\
\hline medium & -0.012 & & -0.055 & & -0.041 & \\
\hline $\max$ & 0.983 & & 2.280 & & 2.139 & \\
\hline R-squared & 0.7192 & & - & & - & \\
\hline AIC & 4504.36 & & -881.9602 & & -1497.52 & \\
\hline $\mathrm{BIC}$ & 4530.68 & & -855.6418 & & -1464.63 & \\
\hline Loglik & -2248.18 & & 444.9801 & & 753.7633 & \\
\hline AME & $1.0069 \mathrm{e}-1$ & & $2.8859 \mathrm{e}-3$ & & $7.9202 \mathrm{e}-4$ & \\
\hline
\end{tabular}

Note: ${ }^{* * *}$ the significance level at $0.01 ;{ }^{1}$ the ID is given as the random terms 
Table 2. The estimated traditional linear model and the mixed-effect models of mature sago palm (6-20y)

\begin{tabular}{|c|c|c|c|c|c|c|}
\hline \multirow{3}{*}{ Variable } & \multirow{2}{*}{\multicolumn{2}{|c|}{$\begin{array}{l}\text { Linear Model } \\
\text { Height } \sim \text { Age + D } \\
\text { (Model 4) }\end{array}$}} & \multicolumn{3}{|c|}{ Mixed Models } & \\
\hline & & & \multicolumn{2}{|c|}{$\begin{array}{l}\text { 1: Height Age } \\
\text { (Model 5) }\end{array}$} & \multicolumn{2}{|c|}{$\begin{array}{l}\text { 2: Height } \sim \text { Age }+ \text { D } \\
\text { (Model 6) }\end{array}$} \\
\hline & Coefficient & S.E. & Coefficient & S.E. & Coefficient & S.E. \\
\hline Intercept & $-5.089^{* * *}$ & 0.092 & - & & - & \\
\hline Diameter & $0.123^{* * *}$ & 0.002 & - & & - & \\
\hline Age & $0.587^{* * *}$ & 0.005 & - & & - & \\
\hline \multicolumn{7}{|c|}{ Random Effect: $\sim 1 \mid \mathrm{ID}^{1}$} \\
\hline Var & - & & 2.264 & 1.179 & $1.9618^{* * * *}$ & 1.102 \\
\hline \multicolumn{7}{|c|}{ Fixed Effects: } \\
\hline Intercept & - & & $-0.970^{* * *}$ & 0.296 & $-2.515^{* * *}$ & 0.305 \\
\hline Age & - & & $0.746^{* * *}$ & 0.012 & $0.681^{* * * *}$ & 0.003 \\
\hline Diameter & - & & & & $0.050^{* * * *}$ & 0.001 \\
\hline \multicolumn{7}{|c|}{ Standardized within-group } \\
\hline \multicolumn{7}{|c|}{ Residuals: } \\
\hline $\min$ & -11.096 & & -8.303 & & -9.545 & \\
\hline medium & -0.056 & & 0.015 & & 0.058 & \\
\hline $\max$ & 6.174 & & 2.280 & & 3.028 & \\
\hline R-squared & 0.8211 & & - & & - & \\
\hline $\mathrm{AIC}$ & 34844.19 & & 26407.71 & & 25299.8 & \\
\hline BIC & 34872.26 & & 26435.78 & & 25334.8 & \\
\hline Loglik & -17418.1 & & -13199.86 & & -12644.9 & \\
\hline AME & $1.01041 \mathrm{e}-8$ & & $0.1786117 \mathrm{e}-10$ & & $0.1648889 \mathrm{e}-$ & \\
\hline
\end{tabular}

Note: ${ }^{* * *}$ the significance level at $0.01 ;{ }^{1}$ the ID is given as the random terms
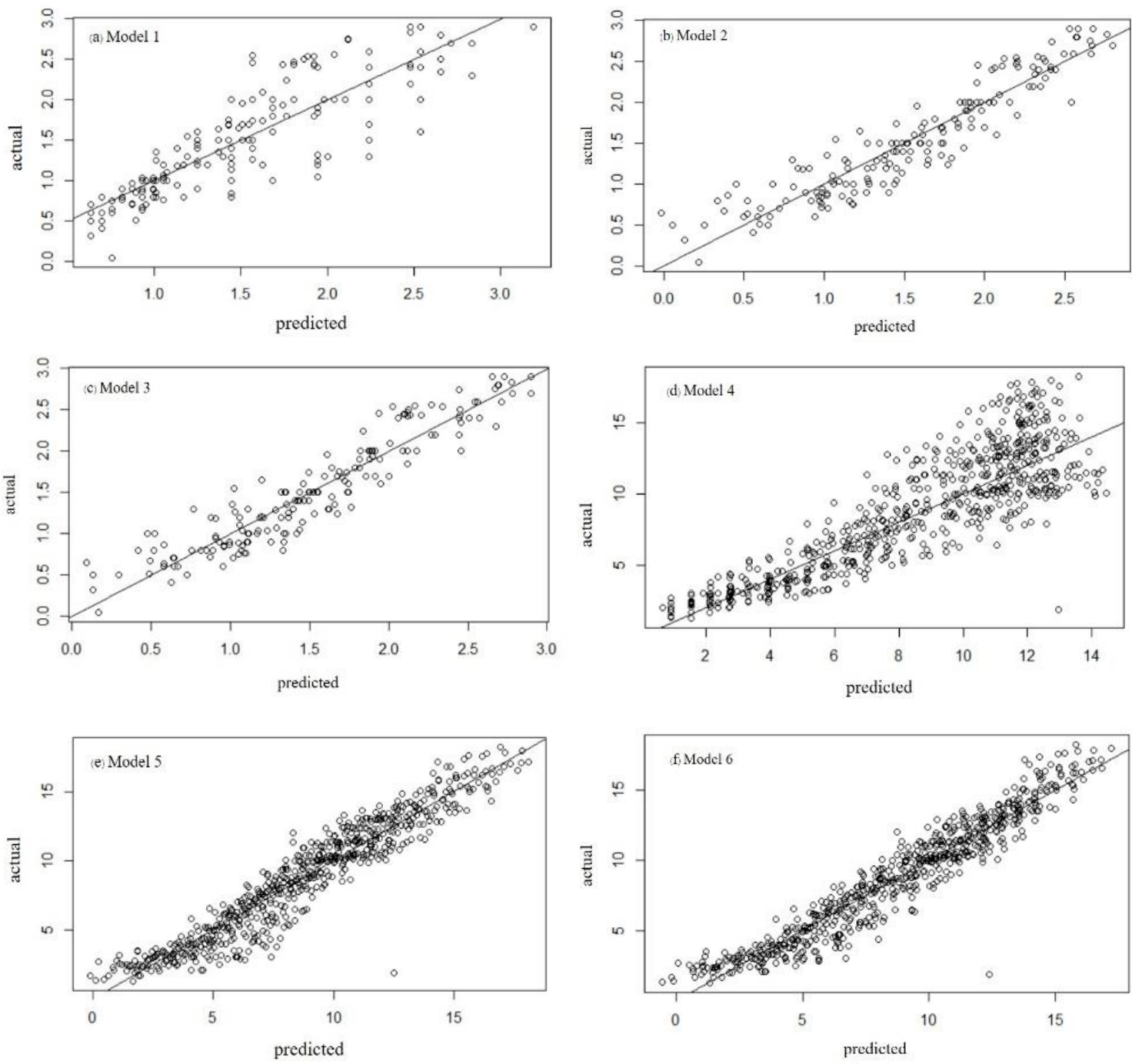

Figure 3. Comparison of the errors between the actual versus predicted values (Young sago palms: Model 1-3; Mature sago palms: Model 4-6) 
Table 3. Growth prediction size compares with other areas

\begin{tabular}{|c|c|c|c|c|c|c|}
\hline \multirow{2}{*}{ Age } & \multicolumn{2}{|c|}{$\begin{array}{l}\text { Predicted growth size } \\
\text { in this study }\end{array}$} & \multicolumn{4}{|c|}{ Actual growth size from other studies } \\
\hline & Mean & S.D. & Height (m) & Location & Sources & Note \\
\hline 2 & $0.86(0.20-1.27)$ & 0.26 & No data & & & \\
\hline 3 & $1.24(0.53-1.73)$ & 0.28 & No data & & & \\
\hline 4 & $1.70(1.11-2.13)$ & 0.29 & No data & & & \\
\hline 5 & $2.28(1.60-3.01)$ & 0.35 & 4.29 & $\begin{array}{l}\text { Inkhiri Subdistrict, Muang District, } \\
\text { Nakhon Si Thammarat Province, } \\
\text { Thailand }\end{array}$ & $\begin{array}{l}\text { Meesang et al. } \\
\text { (2015, unpubl. } \\
\text { data) }\end{array}$ & $\begin{array}{l}\text { Mineral soil, not in the wetland area but near the canal. Averaged from } 265 \text { palms. } \\
\text { The total height was measured at } 30 \mathrm{~cm} \text {. above the ground level. }\end{array}$ \\
\hline 6 & $2.94(0.38-6.59)$ & 1.93 & $5.3(5.2-5.4)$ & Tebing Tinggi, Riau, Indonesia & $\begin{array}{l}\text { Kakuda et al. } \\
(2005)\end{array}$ & $\begin{array}{l}\text { Deep peat (over } 3 \mathrm{~m} \text {.). Averaged from } 3 \text { palms. The palms were transplanted at } 8 \times 8 \mathrm{~m}^{2} \\
\text { spacing, and the sucker was pruning once a year. }\end{array}$ \\
\hline 7 & $3.83(0.80-7.79)$ & 2.06 & $6.8(5.1-8.6)$ & Tebing Tinggi, Riau, Indonesia & $\begin{array}{l}\text { Kakuda et al. } \\
\text { (2005) }\end{array}$ & $\begin{array}{l}\text { Deep peat (over } 3 \mathrm{~m} \text {.). Averaged from } 8 \text { palms. The palms were transplanted at } 8 \times 8 \mathrm{~m}^{2} \\
\text { spacing, and the sucker was pruning once a year. }\end{array}$ \\
\hline 8 & $5.07(1.49-10.57)$ & 2.42 & $7.5+0.9 *$ & Mukah, Sarawak, Malaysia & $\begin{array}{l}\text { Yamamoto et al. } \\
(2003)\end{array}$ & $\begin{array}{l}\text { Mineral soil. The age of the sample palm was } 6.6+0.8 \text { years, which was expressed by } \\
\text { the year after trunk formation at the harvesting stage. The trunk elongation rate was } \\
1.34 \mathrm{~m} / \text { year. }\end{array}$ \\
\hline 9 & $5.92(2.18-11.26)$ & 2.52 & $2.51-4.19$ & Mukah, Sarawak, Malaysia & Jong (1995) & $\begin{array}{l}\text { Deep peat soil. The sampled sago palms were selected from plots with different } \\
\text { planting spaces, consisting of } 4.5,7.5,10.5 \text {, and } 13.5 \mathrm{~m} \text {. }\end{array}$ \\
\hline 10 & $6.67(2.97-11.95)$ & 2.53 & 12.2 & $\begin{array}{l}\text { Totombe, Konda, and Lakomea } \\
\text { villages, Southeast Sulawesi } \\
\text { Province, Indonesia }\end{array}$ & $\begin{array}{l}\text { Yamamoto et al. } \\
(2010)\end{array}$ & $\begin{array}{l}\text { Mineral soil. They selected only Molat variety (The folk varieties in Sulawesi) as the } \\
\text { sample palms. Trunk height was measured from the felled trunk, at the point of the } \\
\text { felled trunk to the attachment position of the leaf sheath of the oldest living leaf on the } \\
\text { trunk. The trunk elongation rate was estimated to be } 1.06 \mathrm{~m} / \mathrm{year} \text {. }\end{array}$ \\
\hline \multirow[t]{2}{*}{11} & $7.43(3.72-12.59)$ & 2.53 & $9.8(9.7-9.9)$ & $\begin{array}{l}\text { Kendari city, Southeat Sulawesi } \\
\text { Province, Indonesia }\end{array}$ & $\begin{array}{l}\text { Yanagidate et al. } \\
\text { (2009) }\end{array}$ & $\begin{array}{l}\text { Mineral soil. They selected only Molat variety (The folk varieties in Sulawesi that is } \\
\text { belonging to spinless) as the sample palms. Trunk height was measured from the felled } \\
\text { trunk, at the point of the felled trunk to the attachment position of the leaf sheath of the } \\
\text { oldest living leaf on the trunk. The trunk elongation rate was estimated to be } 1.09 \\
\mathrm{~m} / \text { year. }\end{array}$ \\
\hline & & & $8.6+1.5^{*}$ & Mukah, Sarawak, Malaysia & $\begin{array}{l}\text { Yamamoto et al. } \\
(2003)\end{array}$ & $\begin{array}{l}\text { Shallow peat soil }(20-30 \mathrm{~cm} \text {. }) \text { The age of the sample palm was } 7.0+1.2 \text { years that was } \\
\text { expressed by the year after trunk formation at the harvesting stage. The trunk } \\
\text { elongation rate was } 1.18 \mathrm{~m} / \text { year. }\end{array}$ \\
\hline 12 & $8.23(4.51-13.28)$ & 2.50 & $8.0+0.5^{*}$ & Dalat, Sarawak, Malaysia & $\begin{array}{l}\text { Yamamoto et al. } \\
(2003)\end{array}$ & $\begin{array}{l}\text { Deep peat soil }(300-450 \mathrm{~cm} \text {.). The age of the sample palm was } 9.6+0.6 \text { years that was } \\
\text { expressed by the year after trunk formation at the harvesting stage. The trunk } \\
\text { elongation rate was } 0.87 \mathrm{~m} / \mathrm{year} \text {. }\end{array}$ \\
\hline 13 & $8.97(5.21-13.95)$ & 2.46 & No data & & & \\
\hline 14 & $9.67(5.95-13.91)$ & 2.39 & No data & & & \\
\hline 15 & $10.49(6.64-14.55)$ & 2.25 & No data & & & \\
\hline 16 & $10.98(6.90-14.83)$ & 2.09 & No data & & & \\
\hline 17 & $11.82(8.34-15.41)$ & 1.91 & No data & & & \\
\hline 18 & $12.38(9.19-15.93)$ & 1.90 & No data & & & \\
\hline 19 & $13.02(9.67-16.57)$ & 1.89 & No data & & & \\
\hline 20 & $13.66(10.51-17.26)$ & 1.84 & No data & & & \\
\hline
\end{tabular}

around three years, whereas, in our sample, the sago was counted as year one from the beginning 


\section{Discussion}

Since there are limited works on growth prediction of the sago palm, we have determined a model to predict the growth of sago palm, using a sample of cultivated sago palm on deep peat soil with a depth of over $2.5 \mathrm{~m}$., using a mixed-effect model of the relationship between age, diameter, and height. The results are expected to fill a gap in current research on the estimated annual incremental living biomass and carbon sequestration equation for sago palm, which can be used to compare this with other crops in the future.

To verify the prediction model, we compared the predicted values with actual growth sizes from the scarcely available literature. It should be noted that the actual size data were retrieved from studies where different conditions existed, and which barely resembled the conditions found in this study. Although some growth size literature from Malaysia and Indonesia exists, where cultivated sago palm is a commercial crop, physical conditions are different. There is one particular study in Thailand, but the study area was on mineral soil, which also differs from this study (Meesang et al. 2015, unpublished data).

The comparison thus shows smaller predicted growth than the actual growth in sago palm from these other areas (Table 3). These smaller sizes can be explained by two factors: different soil types and farm management (Jong and Flach 1995; Kakuda et al. 2005; Yamamoto et al. 2003). In this study, the dataset was from an experiment plot, with sago palms growing on deep peat soil (over 2.5 $\mathrm{m}$ ), while most of the sago palms in other literature grew in mineral and shallow peat soil $(20-30 \mathrm{~cm}$ ) (Yamamoto et al. 2003, 2010; Yanagidate et al. 2009). Only two studies explored sago palm which grew in deep peat soil (over 3 $\mathrm{m})$ : Jong and Flach (1995) and Yamamoto et al. (2003), where researchers studied the growth rate and growth size of sago palms in each stage in deep peat, shallow peat, and mineral soil. The results of these two studies were similar: growing sago palm in deep peat ( $2 \mathrm{~m}$ and above) was less successful than shallow peat and mineral soil. In addition, deep peat soil had the lowest growth. However, when comparing the predicted growth size using the generated model to the actual growth in similar deep peat conditions, the prediction results are well within the actual sizes' range.

Another possible explanation for smaller predicted sizes than the actual sizes is due to farm management. Our experimental plot has not been promoted for a commercial crop, which differs from the ones in Indonesia and Malaysia. For instance, in Malaysia, the Sarawak government encouraged and introduced sago farmers to farm management practices such as sucker pruning, fertilizer application (Naim et al. 2016), and weed management (Ando 2015). Kakuda et al. (2005) found that farm management is important to sago production. One good practice involves retaining the trunk in each clump for continuous harvesting and reducing the density of the sago palm stand as well as the competition for nutrients and light between the parent palm and its suckers. In the experimental plots where we took the dataset, no farm management such as those mentioned above occurred. This is probably the major cause of less growth in our dataset.
Although we lack similar observed data to compare with the predicted data, this study still shows a good performance of the linear mixed-effect model to predict sago palm growth at an individual age covering all 20 years. In past study by Yamamoto et al. $(2003,2010)$, and Yanagidate et al. (2009), the relationship was studied between age and height, using data from several farms gathered within the same year and conducted a simple regression model. We also used a traditional linear regression in this study, but the results demonstrated a lower performance than the linear mixed-effect model. Moreover, we found that the diameter influences the sago palm growth rate, with the smallest value of AIC, BIC, and AME when using both parameters (age and diameter) in the prediction model. Using diameter to predict the growth of sago as in this study has not been investigated in past research. However, to apply this model, careful consideration of the soil type and farm management conditions is needed as the model may not be suitable for determining the growth of cultivated sago palm in mineral soil.

In conclusion, the growth prediction models for sago palm (Metroxylon sagu Rottb.) will advance the calculation of sago palm's ecosystem service benefits, particularly in wetland management where the wetland has been converted to monoculture crops. This information will be crucial for making decisions on land use planning and policy relating to climate change and environmental sustainability. Growing sago palm can be worth considering an alternative to commercial crops for a carbon sequestration mechanism. However, this growth model was based on peat soil data; therefore, future research should focus on the growth prediction of sago palm and establishing a relationship between total height and diameter, especially in mineral soil.

\section{ACKNOWLEDGEMENTS}

The authors would like to thank Pikulthong Peat Swamp Forest Research Station, Pikun Thong Royal Development Study Center, and its staff, especially Mr. Sompong Raksasri, for data support and his kind assistance. The research was financially supported by the Agricultural Research Development Agency and the National Science and Technology Development Agency.

\section{REFERENCES}

Ando H. 2015. Cultivation and management. In: Society of Sago Palm Studies (eds). The Sago Palm: The Food and Environmental Challenges of The 21st Century. Trans Pacific Press, Kyoto.

Bintoro MH, Nurulhaq MI, Pratama AJ, Ahmad F, Ayulia L. 2018. Growing area of sago palm and its environment. In: Ehara H, Toyoda Y, Johnson DV (eds). Sago Palm: Multiple Contributions to Food Security and Sustainable Livelihoods. Springer Nature, Singapore. DOI: 10.1007/978-981-10-5269-9_2.

Bohora SB, Cao QV. 2014. Prediction of tree diameter growth using quantile regression and mixed-effects models. For Ecol Manag 319: 62-66. DOI: 10.1016/j.foreco.2014.02.006.

Chanta S. 2017. Sago palm in Thailand: Status knowledge and sustainable management guidelines. Higher Education Research Promotion and 
National Research University Project of Thailand, Office of the Higher Education Commission. [Thai]

de-Miguel S, Guzmán G, Pukkala T. 2013. A comparison of fixed- and mixedeffects modeling in tree growth and yield prediction of an indigenous neotropical species (Centrolobium tomentosum) in a plantation system. For Ecol Manag 291: 249-258. DOI: 10.1016/j.foreco.2012.11.026.

Fahey TJ, Woodbury PB, Battles JJ, Goodale CL, Hamburg SP, Ollinger SV, Woodall CW. 2010. Forest carbon storage: Ecology, management, and policy. Front Ecol Environ 8 (5): 245-252. DOI: 10.1890/080169.

Food Agriculture and Organization (FAO). 2014. Towards climateresponsible peatlands management. In: Biancalani R, Avagyan A (eds) Mitigation of Climate Change in Agriculture Series (MICCA). http://www.fao.org/3/a-i4029e.pdf

Goodman RC, Phillips OL, del Castillo Torres D, Freitas L, Cortese ST, Monteagudo A, Baker TR. 2013. Amazon palm biomass and allometry. For Ecol Manag 310: 994-1004. DOI: 10.1016/j.foreco.2013.09.045.

Green SM, Page S. 2017. Tropical peatlands: current plight and the need for responsible management. Geol Today 33 (5): 174-179. DOI: $10.1111 /$ gto. 12197

Hergoualc'h K, Verchot LV. 2014. Greenhouse gas emission factors for land use and land-use change in Southeast Asian peatlands. Mitigation Adapt Strategies Glob Change 19 (6): 789-807. DOI: 10.1007/s11027-013-9511-x.

Hirao K, Kondo T, Kainuma K, Takahashi S. 2018. Starch properties and uses as food for human health and welfare. In: Ehara H, Toyoda Y, Johnson DV (eds). Sago Palm: Multiple Contributions to Food Security and Sustainable. Springer Nature, Singapore. DOI: 10.1007/978-981-10-5269-9_21.

Hoffmann MP, Vera AC, van Wijk MT, Giller KE, Oberthür T, Donough C, Whitbread AM. 2014. Simulating potential growth and yield of oil palm (Elaeis guineensis) with PALMSIM: Model description, evaluation and application. Agric Syst 131: 1-10. DOI 10.1016/j.agsy.2014.07.006.

Hydroinformatics Institute (Public Organization) 2020. Annual average rainfall

report http://www.thaiwater.net/media/book/view/dXBsb2Fkcy9jb250ZW50 cy9naXNfYm9vay9ib29rX3NvdXRoLnBkZg== [Thai]

IPCC. 2021. Assessment report 6 climate change 2021: the physical science basis. https://www.ipcc.ch/report/ar6/wg1/

Jong FS. 1995. Research for The Development of Sago Palm (Metroxylon sagu Rottb.) Cultivation in Sarawak Malaysia. [Dissertation]. Wageningen University and Research, Wageningen, Netherland.

Jong FS, Flach M. 1995. The sustainability of sago palm (Metroxylon sagu) cultivation on deep peat in Sarawak. Sago Palm 3 (1): 13-20.

Kakuda K, Watanabe A, Ando H, Jong FS. 2005. Effects of fertilizer application on the root and aboveground biomass of Sago Palm (Metroxylon sagu Rottb.) cultivated in peat soil. J Trop Agric 49 (4): 264-269. DOI: 10.11248 /jsta1957.49.264

Koh LP, Miettinen J, Liew SC, Ghazoul J. 2011. Remotely sensed evidence of tropical peatland conversion to oil palm. Proc Natl Acad Sci USA 108 (12): 5127-5132. DOI: 10.1073/pnas.1018776108.

Lieberman M, Lieberman D, Vadermeer JH. 1988. Age-size relationships and growth behavior of the palm Welfia georgii. Biotropoca 20 (4) 270-273. DOI: $10.2307 / 2388315$

Miettinen J, Shi C, Liew SC. 2012. Two decades of destruction in Southeast Asia's peat swamp forests. Front Ecol Environ 10 (3): 124-128. DOI: $10.1890 / 100236$.

Miettinen J, Shi C, Liew SC. 2016. Land cover distribution in the peatlands of Peninsular Malaysia, Sumatra and Borneo in 2015 with changes since 1990. Glob Ecol Conserv 6: 67-78. DOI: 10.1016/j.gecco.2016.02.004.

Morel AC, Saatchi SS, Malhi Y, Berry NJ, Banin L, Burslem D, Burslem D. Ong RC. 2011. Estimating aboveground biomass in forest and oil palm plantation in Sabah, Malaysian Borneo using ALOS PALSAR data. For Ecol Manag 262 (9): 1786-1798. DOI: 10.1016/j.foreco.2011.07.008.

Nabeya K, Nakamura S, Nakamura T, Fujii A, Watanabe M, Nakajima T, Nitta Y, Goto Y. 2015. Growth behavior of sago palm (Metroxylon sagu Rottb.) from transplantation to trunk formation. Plant Prod Sci 18 (2): 209-217. DOI: 10.1626/pps.18.209.
Naim HM, Yaakub AN, Hamdan DAA. 2016. Commercialization of sago through estate plantation scheme in Sarawak: the way forward. Intl J Agron. DOI: 10.1155/2016/8319542.

Nattharom N, Roongtawanreongsri S, Bumrungsri S. 2020. Growth prediction for rubber trees and intercropped forest trees to facilitate environmental services valuation in South Thailand. Biodiversitas 21 (5): 2019-2034. DOI: $10.13057 /$ biodiv/d210528

Nitta Y. 2015. Morphology. In: Society of Sago Palm Studies (eds). The Sago Palm: The Food and Environmental Challenges of The 21st Century. Trans Pacific Press, Kyoto.

Ohmi M. 2015. Starch properties and uses. In: Society of Sago Palm Studies (eds). The Sago Palm: The Food and Environmental Challenges of The $21^{\text {st }}$ Century. Trans Pacific Press, Kyoto.

Pearson T, Walker S, Brown S. 2013. Sourcebook for land use, land-use change and forestry projects. Winrock International and the BioCarbon Fund of the World Bank 21 (3): 64. http://wbcarbonfinance.org/docs/Background_LULUCF_Sourcebook_co mpressed.pdf

Rodríguez ACC. 2017. Above-Ground Biomass Estimation in Palm Trees Using Terrestrial LiDAR and Tree Modelling. [Dissertation]. Wageningen University and Research, Wageningen, Netherland.

Saaludin N, Harun S, Yahya Y, Ahmad WSCW. 2014. Modeling individual tree diameter increment for Dipterocarpaceae and nonDipterocarpaceae in tropical rainforest. Proceedings of the 8th International Conference on Ubiquitous Information Management and Communication (ICUIMC). Siem Reap, Cambodia, 9-11 January 2014. DOI: $10.1145 / 2557977.2557992$.

Singh A, Dhakad AK. 2018. Growth prediction model for eucalyptus hybrid in $\begin{array}{lllllll}\text { India. J Trop For Sci } 30 & \text { (4): 576-587. DOI: }\end{array}$ 10.26525/jifs2018.30.4.576587.

Socha J, Tymińska-Czabańska L, Bronisz K, Zięba S, Hawryło P. 2021. Regional height growth models for Scots pine in Poland. Sci Rep 11(1): 1-14. DOI: 10.1038/s41598-021-89826-9.

Susanto D, Hayatudin, Setiawan A, Purnomo H, Ruhiyat D, Amirta R. 2017. Characterizing nutrient status and growth of Macaranga gigantea in tropical rainforest gaps after selective logging in East Kalimantan, $\begin{array}{lllll}\text { Indonesia. } & \text { Biodiversitas } 18 & \text { (3): } 996-1003 . & \text { DOI: }\end{array}$ 10.13057/biodiv/d180318.

Thorburn CC, Kull CA. 2015. Peatlands and plantations in Sumatra, Indonesia: Complex realities for resource governance, rural development and climate change mitigation. Asia Pac Viewpoint 56 (1): 153-168. DOI: 10.1111/apv.12045.

Toyoda Y. 2015. Diversity of Used. In: Society of Sago Palm Studies (eds). The Sago Palm: The Food and Environmental Challenges of the $21^{\text {st }}$ Century. Trans Pacific Press, Kyoto.

Uda SK, Hein L, Adventa A. 2020. Towards better use of Indonesian peatlands with paludiculture and low-drainage food crops. Wetl Ecol Manag 28 (3): 509-526. DOI: 10.1007/s11273-020-09728-x.

Vashum TV, Jayakumar S. 2012. Methods to estimate above-ground biomass and carbon stock in natural forests - a review. J Ecosyst Ecograph 2 (4): 2-7. DOI: 10.4172/2157-7625.1000116.

Wulan S, Kusnoputranto H, Supriatna J, Djoefrie HMHB, AL Hakim HM. 2015. Life cycle assessment of Sago Palm, Oil Palm, and Paddy cultivated on peatland. J Wetlands Environ Manag 3 (1): 14-21.

Yamamoto Y, Yoshida T, Goto Y, Nitta Y, Kakuda K, Jong FS, Hilary LB, Hassan AH. 2003. Differences in growth and starch yield of Sago Palms (Metroxylon sagu Rottb.) among soil types in Sarawak, Malaysia. Jpn J Trop Agric 47 (4): 250-259. DOI: 10.11248/jsta1957.47.250.

Yamamoto Y, Rembon FS, Omori K, Yoshida T, Nitta Y, Pasolon YB, Miyazaki A. 2010. Growth characteristics and starch productivity of three varieties of Sago Palm (Metroxylon sagu Rottb.) in Southeast Sulawesi, Indonesia. Trop Agr Develop 51 (1): 1-8.

Yanagidate I, Rembon FS, Yoshida T, Yamamoto Y, Pasolon YB, Jong FS, Irawan AF, Miyazaki A. 2009. Studies on trunk density and prediction of starch productivity of sago palm (Metroxylon sagu Rottb.): a case study of a cultivated sago palm garden near Kendari, Southeast Sulawesi Province, Indonesia. Sago Palm 17: 1-8. 